\title{
PMAIP1 wt Allele
}

National Cancer Institute

\section{Source}

National Cancer Institute. PMAIP1 wt Allele. NCI Thesaurus. Code C49393.

Human PMAIP1 wild-type allele is located in the vicinity of 18q21.32 and is approximately $4 \mathrm{~kb}$ in length. This allele, which encodes phorbol-12-myristate-13-acetate-induced protein 1 , is a mediator of p53-dependent apoptosis. 